\title{
Insidens Defisiensi Besidan Anemia Defisiensi Besi pada Bayi Berusia 0-12 Bulan di Banjarbaru Kalimantan Selatan: studi kohort prospektif
}

\author{
Harapan Parlindungan Ringoringo \\ Bagian Anak Fakultas Kedokteran Universitas Lambung Mangkurat, RSUD Banjarbaru-Kalimantan Selatan
}

Latar belakang. Anemia defisiensi besi (ADB) merupakan salah satu masalah kesehatan gizi di Indonesia. Survei kesehatan rumah tangga (SKRT) tahun 2001 menunjukkan prevalensi ADB pada bayi kurang dari 1 tahun $55 \%$.

Tujuan. Mengetahui insidens deplesi besi, defisiensi besi, dan anemia defisiensi besi pada bayi berusia kurang dari 1 tahun.

Metode. Desain penelitian adalah studi kohort prospektif dengan pembanding eksternal. Dijumpai 211 bayi ikut dalam penelitian, terdiri dari 143 bayi lahir dari ibu tanpa anemia dan 68 bayi lahir dari ibu dengan anemia. Pemeriksaan darah tepi lengkap, gambaran darah tepi, feritin, saturasi transferin (ST) dilakukan saat bayi berusia 0, 1, 2, 3, 4, 5, 6, dan 12 bulan. Diagnosis ADB berdasarkan 1) kadar hemoglobin <14g/dL untuk usia 0-3 hari, $<11 \mathrm{~g} / \mathrm{dL}$ usia 1 bulan, $<10 \mathrm{~g} / \mathrm{dL}$ usia 2-6 bulan, $<11 \mathrm{~g} / \mathrm{dL}$ usia 6-12 bulan, 2) mikrositik dan atau hipokrom, 3) kadar hemoglobin meningkat setelah diberi terapi besi, 4) feritin $<12 \mathrm{ug} / \mathrm{L}$ usia 6-12 bulan, 5) $\mathrm{RDW}>14 \%, 6)$ Indeks Mentzer $>13$; 7) Indeks RDW $>220$. Deplesi besi bila $S T<30 \%$ untuk usia 0-1 bulan, ST $<21 \%$ untuk usia 2-6 bulan, feritin $<20$ ug/L usia 6-12 bulan. Defisiensi besi bila ST $<20 \%$ usia 0-1 bulan, ST $<16 \%$ usia $2-6$ bulan, feritin $<12$ ug/L usia 6-12 bulan.

Hasil. Insidens deplesi besi, defisiensi besi, ADB berturut-turut 11,4\%, 7,6\%, 47,4\%, tertinggi pada bayi berusia 0 bulan, yaitu berturut-turut 9,5\%, 14,2\%, 11,8\%.

Kesimpulan. Insidens deplesi besi, defisiensi besi, ADB paling tinggi dijumpai pada bayi berusia 0 bulan. (Sari Pediatri 2009;11(1):8-14).

Kata kunci: deplesi besi, defisiensi besi, ADB, bayi

\section{Alamat korespondensi}

Dr. dr. Harapan Parlindungan Ringoringo, Sp.A(K). RSUD Banjarbaru. Jl. Palang Merah No.2 Banjarbaru - Kalimantan Selatan 70712. Email: hprspa@yahoo.com
A

nemia defisiensi besi (ADB) adalah salah satu masalah kesehatan gizi utama di dunia, di Asia Tenggara, termasuk di Indonesia. enelitian Schneider $\mathrm{dkk}^{1}$ di negara bagian California Amerika Serikat tahun 2002 pada 498 anak berusia 12 sampai dengan 36 bulan dari keluarga berpenghasilan rendah menemukan prevalensi ADB 
3,4\%. Prevalensi anemia pada anak balita di negaranegara berkembang sekitar $40 \%-45 \% .^{2}$ Di Chili, Lozoff $^{3}$ melaporkan prevalensi defisiensi besi diantara 1657 bayi berusia 1 tahun 34,9\%, dan dari 186 bayi anemia $84,9 \%$ disebabkan oleh ADB. Di Indonesia ADB merupakan salah satu masalah kesehatan gizi utama. Data SKRT tahun 2001 menunjukkan prevalensi $\mathrm{ADB}$ pada bayi $<1$ tahun, dan bayi 0-6 bulan berturut-turut $55 \%$ dan $61,3 \% .^{4}$ Suatu penelitian terhadap 990 bayi Indonesia berusia 3-5 bulan, menunjukkan prevalensi ADB $71 \% .^{2}$

Prevalensi defisiensi besi atau ADB pada balita atau anak di bawah umur satu tahun yang tinggi tidak terlepas dari prevalensi defisiensi besi atau ADB pada wanita hamil. Data SKRT tahun 2001 menunjukkan prevalensi ADB pada wanita hamil $40,1 \% .^{4}$ Banyak faktor risiko mempengaruhi prevalensi defisiensi besi atau ADB pada bayi yang dilahirkan. Salah satu faktor risiko yang paling berperan adalah apakah ibu menderita anemia atau tidak selama hamil. Pee $\mathrm{dkk}^{5}$ melaporkan, bayi (berat lahir $>2500$ gram) yang lahir dari ibu anemia mempunyai kadar hemoglobin yang lebih rendah dibandingkan bayi yang lahir dari ibu tanpa anemia.

Manifestasi klinis ADB yang paling serius adalah gangguan fungsi otak di kemudian hari berupa gangguan perkembangan motorik, kemampuan kognitif berkurang, gangguan perilaku, gangguan pendengaran, gangguan penglihatan, dan gangguan mielinisasi yang menetap. ${ }^{6-8}$

Beberapa penelitian menunjukkan bahwa kadar $\mathrm{Hb}$, VER, feritin, saturasi transferin mulai menurun pada usia 2-3 bulan. ${ }^{9-11}$ Namun kapan mulai terjadi deplesi besi, defisiensi besi tanpa anemia dan ADB belum diketahui pasti. Tujuan penelitian untuk mengetahui insidens deplesi besi, defisiensi besi, anemia defisiensi besi, dan kapan mulai terjadi deplesi besi atau defisiensi besi sebelum terjadi ADB pada bayi berusia 0 sampai dengan 12 bulan.

\section{Metode}

Desain penelitian adalah studi kohort prospektif dengan pembanding eksternal (studi kohort ganda). Penelitian dilaksanakan di wilayah Kotamadya Banjarbaru Kalimantan Selatan, mulai bulan Juli 2006 sampai dengan Maret 2008. Penelitian telah mendapat ethical clearance (lolos kaji etik) dari Panitia Etik FKUI Jakarta, dan semua subjek penelitian menyetujui inform consent yang diberikan oleh peneliti.

Sampel terjangkau adalah semua ibu dan bayinya yang memenuhi kriteria inklusi dan tidak memenuhi kriteria eksklusi. Sampel diambil secara consecutive (berurutan) sampai jumlah subjek yang diperlukan terpenuhi. Kriteria inklusi untuk ibu adalah bersedia diikutsertakan dalam penelitian, tidak menderita sakit berat selama kehamilannya, tidak menderita perdarahan antepartum, dan kriteria ibu tidak diikutsertakan dalam penelitian bila menderita penyakit hematologik-onkologi. Kriteria inklusi untuk bayi adalah orang tua mengijinkan bayinya diikutsertakan dalam penelitian, bayi lahir bugar (warna kulit merah, laju nadi $>100 \mathrm{x} /$ menit, menangis kuat), lahir aterm dengan berat lahir $\geq 2500$ g, tidak menderita kelainan kongenital mayor. Bayi tidak diikutsertakan dalam penelitian bila menderita sakit berat selama periode penelitian, menderita penyakit hematologik-onkologi selama periode penelitian, selama dalam periode penelitian karena suatu hal orang tua tidak bersedia bayinya diikutsertakan lagi dalam penelitian.

Ibu dikelompokkan menjadi kelompok I ibu tanpa anemia bila $\mathrm{Hb} \geq 11 \mathrm{~g} / \mathrm{dL}$, dan kelompok II untuk ibu dengan anemia bila $\mathrm{Hb}<11$ g/dL. ${ }^{2,12,13}$ Pada bayi dilakukan pemeriksaan darah tepi lengkap, gambaran darah tepi, saturasi transferin, feritin saat bayi berusia $0,1,2,3,4,5,6$, dan 12 bulan. Darah vena diambil dari vena di fossa cubiti atau di dorsum manus. Bahan darah segera dikirim ke laboratorium PRODIA untuk pemeriksaan saturasi transferin dan feritin, sampel dikirim ke laboratorium SEAMEO TROPMED dan Laboratorium Patologi Klinik RS Dr Ciptomangunkusumo Jakarta.

\section{Pemeriksaan laboratorium}

Pemeriksaan darah tepi lengkap dilakukan dengan alat counter SWALAB dan gambaran darah tepi dilihat dengan mikroskop pada pembesaran 1000X.

Pemeriksaan serum iron (SI) dan unsaturated iron binding capacity (UIBC) menggunakan reagens dari Roche dan dikerjakan dengan alat Roche / Hitachi analyzer 917. Nilai total iron binding capacity (TIBC) diperoleh dengan rumus TIBC $=$ SI + UIBC. Nilai transferrin saturation (TS) diperoleh dengan rumus TS $(\%)=$ SI - TIBC $\mathrm{x}$ 100\%. Pemeriksaan feritin dilakukan dengan teknik sandwich ELISA dan alat ELISA reader. ${ }^{14}$ 


\section{Batasan operasional}

Diagnosis ADB pada bayi ditegakkan berdasarkan kadar $\mathrm{Hb}$ lebih kecil dari batas bawah nilai normal $(<14 \mathrm{~g} / \mathrm{dL}$ untuk $0-3$ hari, $<11 \mathrm{~g} / \mathrm{dL}$ untuk 1 bulan, $<10 \mathrm{~g} / \mathrm{dL}$ untuk 2-6 bulan, $<11 \mathrm{~g} / \mathrm{dL}$ untuk 6-12 bulan), gambaran darah tepi menunjukkan mikrositik dan atau hipokrom, kadar $\mathrm{Hb}$ meningkat setelah diberi terapi besi elemental selama 2 bulan, kadar feritin $<12 \mathrm{ug} / \mathrm{L}$ untuk usia 6-12 bulan, RDW $>14 \%$, indeks Mentzer $>13$ indeks RDW $>220 .{ }^{15-18}$ Diagnosis ADB ditegakkan bila kriteria pada butir 1,2,3,4 terpenuhi ditambah $\geq 1$ dari 3 kriteria pada butir 5,6,7.

Diagnosis deplesi besi ditegakkan berdasarkan kadar $\mathrm{Hb}$ normal untuk usia tertentu, saturasi transferin $<30 \%$ untuk usia $0-1$ bulan, dan saturasi transferin $<21 \%$ untuk usia $2-6$ bulan, feritin $<20$ ug/L untuk usia 6-12 bulan. Diagnosis defisiensi besi

Tabel 1. Karakteristik demografi ibu tanpa anemia dan ibu dengan anemia

\begin{tabular}{|c|c|c|c|c|}
\hline \multicolumn{2}{|l|}{ Variabel ibu } & $\begin{array}{c}\text { Rerata }(\mathrm{SD}) \\
\text { Ibu tanpa anemia } \\
\mathrm{Hb}>11 \mathrm{~g} / \mathrm{dL} \\
\mathrm{n}=143\end{array}$ & $\begin{array}{c}\text { Rerata }(\mathrm{SD}) \\
\text { Ibu dengan anemia } \\
\mathrm{Hb}<11 \mathrm{~g} / \mathrm{dL} \\
\mathrm{n}=68\end{array}$ & $p$ \\
\hline \multicolumn{2}{|c|}{ Umur (tahun) } & $29,2(5,7)$ & $28,5(6,3)$ & 0,41 \\
\hline \multicolumn{2}{|c|}{ Masa gestasi (minggu) } & $\begin{aligned} & 39,6(1,0) \\
\rightarrow & \text { Median } 40\end{aligned}$ & $\begin{aligned} & 39,7(0,7) \\
\rightarrow & \text { Median } 40\end{aligned}$ & 0,16 \\
\hline \multicolumn{2}{|l|}{ Paritas (\%) } & & & 0,51 \\
\hline \multicolumn{2}{|l|}{$0-2$} & $113(79,0)$ & $51(75,0)$ & \\
\hline \multirow{2}{*}{\multicolumn{2}{|c|}{$\begin{array}{l}>2 \\
\text { Pendidikan (\%) }\end{array}$}} & $30(21,0)$ & $17(25,0)$ & 0,52 \\
\hline & & & & \\
\hline \multicolumn{2}{|c|}{ Rendah } & $21(14,7)$ & $14(20,6)$ & 0,16 \\
\hline \multicolumn{2}{|l|}{ Menengah } & $87(60,8)$ & $37(54,4)$ & \\
\hline \multicolumn{2}{|l|}{ Tinggi } & $35(24,5)$ & $17(25,0)$ & 0,68 \\
\hline \multicolumn{2}{|c|}{ Pekerjaan (\%) } & & & 0,90 \\
\hline \multicolumn{2}{|c|}{ Tidak bekerja } & $119(83,2 \%)$ & $51(75,0)$ & 0,91 \\
\hline \multicolumn{2}{|l|}{ Bekerja } & $24(16,8 \%)$ & $17(25,0)$ & \\
\hline \multicolumn{2}{|c|}{ Status ekonomi keluarga (\%) } & & & 0,58 \\
\hline \multicolumn{2}{|c|}{ Miskin } & $122(85,3)$ & $56(82,4)$ & 0,04 \\
\hline \multicolumn{2}{|c|}{ Tidak miskin } & $21(14,7)$ & $12(17,6)$ & \\
\hline \multicolumn{2}{|c|}{ Berat badan sebelum hamil (kg) } & $50,1(9,4)$ & $50,0(10,7)$ & 0,27 \\
\hline \multicolumn{2}{|c|}{ Berat badan saat melahirkan (kg) } & $60,8(10,3)$ & $60,6(12,8)$ & $<0,001$ \\
\hline \multicolumn{2}{|c|}{ Perawatan antenatal $(\%)$} & & & $<0,001$ \\
\hline \multicolumn{2}{|c|}{ Bukan dokter } & $89(62,2)$ & $45(66,2)$ & $<0,001$ \\
\hline \multicolumn{2}{|c|}{ Dokter ahli kandungan } & $54(37,8)$ & $23(33,8)$ & $<0,001$ \\
\hline \multicolumn{2}{|c|}{ Jumlah kunjungan antenatal selama hamil } & $8,3(2,8)$ & $7,6(2,6)$ & $<0,001$ \\
\hline \multicolumn{2}{|c|}{ Jenis persalinan (\%) } & $\rightarrow$ Median 9 & $\rightarrow$ Median 8 & $<0,001$ \\
\hline \multicolumn{2}{|c|}{ Spontan } & & & $<0,001$ \\
\hline \multirow{2}{*}{\multicolumn{2}{|c|}{$\begin{array}{l}\text { Dengan tindakan } \\
\text { Laboratorium }\end{array}$}} & $111(77,6)$ & $49(72,1)$ & 0,49 \\
\hline & & $32(22,4)$ & $19(27,9)$ & 0,64 \\
\hline$\sum$ Eritrosit & $106 / \mathrm{uL}$ & $4,4(0,4)$ & $3,8(0,5)$ & 0,08 \\
\hline $\mathrm{Ht}$ & $\%$ & $37,4(2,6)$ & $31,1(2,9)$ & 0,45 \\
\hline VER & um3 & $86,1(5,6)$ & $81,6(7,5)$ & \\
\hline RDW & $\%$ & $15,1(1,7)$ & $16,0(2,1)$ & \\
\hline $\mathrm{Hb}$ & $\mathrm{g} / \mathrm{dL}$ & $12,2(1,0)$ & $10,0(0,9)$ & \\
\hline HER & pg & $28,2(2,2)$ & $26,2(2,8)$ & \\
\hline KHER & $\mathrm{g} / \mathrm{dL}$ & $32,8(0,9)$ & $32,1(1,0)$ & \\
\hline Trombosit & 103/uL & $266,7(29,1)$ & $242,7(69,6)$ & \\
\hline Leukosit & 103/uL & $11,7(4,8)$ & $11,4(4,7)$ & \\
\hline sTfR & $\mathrm{mg} / \mathrm{L}$ & $9,0(4,4)$ & $10,4(6,3)$ & \\
\hline Feritin & $\mathrm{ug} / \mathrm{L}$ & $30,9(40,5)$ & $26,8(40,6)$ & \\
\hline
\end{tabular}


ditegakkan berdasarkan kadar $\mathrm{Hb}$ normal untuk usia tertentu, saturasi transferin $<20 \%$ untuk usia $0-1$ bulan, saturasi transferin $<16 \%$ untuk usia $2-6$ bulan, feritin $<12 \mathrm{ug} / \mathrm{L}$ untuk usia 6-12 bulan. ${ }^{17,19,20}$ Bila bayi menderita $\mathrm{ADB}$ maka bayi mendapat terapi oral preparat ferri $(\mathrm{Fe})$ selama 2-4 bulan dengan dosis $\mathrm{Fe}$ elemental 4-5 mg/kgBB/hari, 1-3 kali sehari sebelum minum susu atau makan. Data diolah dengan program SPSS 15.0 dan STATA Intercool 9.2.

\section{Hasil}

Ibu yang ikut sebagai subjek penelitian 220 orang, dan hanya 9 orang $(4,09 \%)$ yang tidak diikutkan dalam analisis karena 7 orang menolak melanjutkan penelitian serta 2 orang mempunyai data laboratorium tidak lengkap.

Kelompok ibu tanpa anemia mempunyai 143 bayi yang terdiri dari 83 laki-laki dan 60 perempuan,

Tabel 2. Insidens ADB pada bayi berusia 0-6 bulan dan 0-12 bulan

\begin{tabular}{|c|c|c|c|}
\hline \multirow{2}{*}{ Ibu dengan anemia } & \multicolumn{2}{|c|}{ Bayi $0-6$ bulan } & \multirow{2}{*}{ Jumlah } \\
\hline & Bayi dengan $\mathrm{ADB}$ & Bayi tanpa ADB & \\
\hline Ya (\%) & $30(44,1)$ & $38(55,9)$ & $68(100)$ \\
\hline Tidak (\%) & $56(39,2)$ & $87(60,8)$ & $143(100)$ \\
\hline Jumlah (\%) & $86(40,8)$ & $125(59,2)$ & $211(100)$ \\
\hline \multirow{2}{*}{ Ibu dengan anemia } & \multicolumn{2}{|c|}{ Bayi $0-12$ bulan } & \\
\hline & Bayi dengan $\mathrm{ADB}$ & Bayi tanpa ADB & Jumlah \\
\hline Ya (\%) & $37(54,4)$ & $31(45,6)$ & $68(100)$ \\
\hline Tidak (\%) & $63(44,1)$ & $80(55,9)$ & $143(100)$ \\
\hline Jumlah (\%) & $100(47,4)$ & $111(52,6)$ & $211(100)$ \\
\hline
\end{tabular}

Tabel 3. Insidens deplesi besi dan defisiensi besi pada bayi berusia 0-6 bulan

\begin{tabular}{lccccc}
\hline \multirow{2}{*}{ Ibu dengan anemia } & \multicolumn{5}{c}{ Bayi $0-6$ bulan } \\
\cline { 2 - 6 } & \multicolumn{4}{c}{ Deplesi besi } & \multicolumn{4}{c}{ Defisiensi besi } & Jumlah \\
\cline { 2 - 6 } & $(+)$ & $(-)$ & $(+)$ & $(-)$ & Jumlah \\
\hline Ya (\%) & $22(32,4)$ & $46(67,6)$ & $11(16,2)$ & $57(83,8)$ & $68(100)$ \\
Tidak (\%) & $37(25,9)$ & $106(74,1)$ & $46(32,2)$ & $97(67,8)$ & $143(100)$ \\
\hline Jumlah (\%) & $59(28,0)$ & $152(72,0)$ & $57(27,0)$ & $154(73,0)$ & $211(100)$ \\
\hline \multirow{5}{*}{ Ibu dengan anemia } & \multicolumn{5}{c}{ Deplesi 0-12 bulan } \\
\cline { 2 - 6 } & $(+)$ & $(-)$ & $(+)$ & $(-)$ & Jumlah \\
\hline Ibu dengan anemia (\%) & $7(10,3)$ & $61(89,7)$ & $4(5,9)$ & $64(94,1)$ & $68(100)$ \\
Ibu tanpa anemia (\%) & $17(11,9)$ & $126(88,1)$ & $12(8,4)$ & $131(91,6)$ & $143(100)$ \\
\hline Jumlah (\%) & $24(11,4)$ & $187(88,6)$ & $16(7,6)$ & $195(92,4)$ & $211(100)$ \\
\hline
\end{tabular}

Tabel 4. Insidens ADB pada bayi berusia 0 sampai 12 bulan

\begin{tabular}{llccccccccc}
\hline \multirow{2}{*}{ ADu } & Ibu & \multicolumn{8}{c}{ Umur bayi (bulan) } & \multirow{2}{*}{ Jumlah } \\
\cline { 2 - 11 } & & 0 & 1 & 2 & 3 & 4 & 5 & 6 & 12 & \\
\cline { 2 - 10 } & Dengan anemia (n) & 9 & 7 & 7 & 4 & 2 & 0 & 1 & 7 & 37 \\
& Tanpa anemia (n) & 16 & 16 & 17 & 5 & 1 & 0 & 1 & 7 & 63 \\
\hline & Jumlah & 25 & 23 & 24 & 9 & 3 & 0 & 2 & 14 & 100 \\
\hline
\end{tabular}


sedangkan kelompok ibu dengan anemia mempunyai 68 bayi terdiri dari 38 laki-laki dan 30 perempuan. Karakteristik demografi subjek penelitian (ibu) tertera pada Tabel 1. Karakteristik demografi kedua kelompok hampir sama $(p>0,05)$, sehingga kedua kelompok dapat dibandingkan pada variabel yang akan diteliti. Hasil laboratorium memperlihatkan indeks eritrosit kedua kelompok berbeda $(p<0,001)$, sehingga kedua kelompok layak dibandingkan apakah bayi yang dilahirkan ibu cenderung lebih mudah menderita defisiensi besi.

Pada Tabel 2 tertera insidens ADB bayi usia 0 sampai 6 bulan dari ibu dengan anemia dan ibu tanpa anemia berturut-turut $44,1 \%$ dan $39,2 \%$, secara keseluruhan insidens ADB 40,8\%. Pada pemantauan 6 bulan berikutnya insidens ADB makin meningkat menjadi $47,4 \%$.

Pada pengamatan saat usia bayi 0-6 bulan, dari 125 bayi yang tidak menderita $\mathrm{ADB}$ dilakukan pemeriksaan saturasi transferin untuk menetapkan apakah seorang bayi menderita deplesi besi, defisiensi besi, atau normal. Berdasarkan hasil pemeriksaan saturasi transferin didapatkan 59 bayi menderita deplesi besi, 57 bayi menderita defisiensi besi, dan 9 bayi normal (Tabel 3). Pada pengamatan 6 bulan berikutnya (usia bayi 6-12 bulan) ternyata 24 bayi tetap menderita deplesi besi, 16 bayi tetap menderita defisiensi besi, 14 bayi menderita ADB (9 bayi dari bayi yang sebelumnya menderita defisiensi besi dan 5 bayi dari bayi yang sebelumnya menderita deplesi besi) seperti tertera pada Tabel 3 dan 4.

Insidens deplesi besi pada bayi berusia 0 bulan sampai 12 bulan secara keseluruhan 11,4\% dari 211 bayi. Insidens defisiensi besi pada bayi berusia 0 bulan sampai 12 bulan secara keseluruhan 7,6\% dari 211 bayi. Insidens $\mathrm{ADB}$ cenderung lebih sering terjadi pada bayi berusia $0-2$ bulan [72 bayi (72\%) dari 100 bayi ADB] dan 12 bulan, baik pada bayi yang lahir dari ibu dengan anemia maupun yang lahir dari ibu tanpa anemia. Jadi insidens $\mathrm{ADB}$ pada bayi umur 0 , 1, dan 2 bulan berturut-turut adalah 11,8\%, 10,9\%, dan $11,3 \%$.

\section{Pembahasan}

Insidens $\mathrm{ADB}$ pada bayi berusia 0 sampai 12 bulan dari ibu dengan anemia dan ibu tanpa anemia berturut-turut $54,4 \%$ dan $44,1 \%$. Secara keseluruhan insidens $\mathrm{ADB} 47,4 \%$, berbeda dengan laporan Siegel $\mathrm{dkk}^{21}$ di Nepal terhadap 490 bayi berusia 4-17 bulan menemukan angka prevalensi $\mathrm{ADB} 43,1 \%$. Sekartini $\mathrm{dkk}^{22}$ dalam penelitiannya terhadap 55 bayi berusia 4-12 bulan di empat Puskesmas Kecamatan Jakarta Timur tahun 2004 mendapatkan 38,2\% bayi mengalami anemia, dan $71,4 \%$ bayi anemia tersebut menderita ADB. Ringoringo ${ }^{23}$ 2005, dalam penelitiannya terhadap 104 bayi berusia 0-6 bulan di RSUD Banjarbaru Banjarmasin mendapatkan prevalensi ADB sebesar 38,5\%.

Setelah dilakukan uji bivariat, ternyata bayi yang lahir dari ibu dengan anemia mempunyai risiko yang hampir sama untuk menderita ADB bila dibandingkan dengan bayi yang lahir dari ibu tanpa anemia $(p<0,05)$. Meskipun risiko hampir sama namun ada kecenderungan bayi yang lahir dari ibu dengan anemia lebih berisiko menderita ADB daripada bayi yang lahir dari ibu tanpa anemia. Jadi dapat diduga faktor risiko $\mathrm{Hb}$ ibu mempunyai pengaruh terhadap status besi bayi yang dikandungnya. Meinzen-Derr $\mathrm{dkk}^{24}$ dalam penelitiannya menemukan bayi yang lahir dari ibu dengan anemia mempunyai risiko tiga kali lipat menderita anemia $(p=0,03)$.

Sejauh ini belum ada laporan insidens deplesi besi atau defisiensi besi pada bayi berusia 0 sampai 6 bulan, karena memang gold standar cut-off point kadar feritin, sTfR maupun indeks sTfR-F untuk penetapan seorang bayi deplesi besi atau defisiensi besi pada bayi 0-6 bulan belum ada. Karena itu untuk menetapkan apakah seorang bayi menderita deplesi besi, defisiensi besi, atau normal dilakukan pemeriksaan saturasi transferin. Pemeriksaan saturasi transferin dianggap sebagai gold standar karena pemeriksaan tersebut dapat membedakan deplesi besi dari defisiensi besi dan batasan angka yang dipilih adalah yang terendah ditemukan di dalam kepustakaan. ${ }^{19,20}$ Kemungkinan pengaruh variasi diurnal dapat disingkirkan (paling tidak sangat dikecilkan) oleh karena semua sampel darah bayi diambil pada pagi hari. Ervasti $\mathbf{d k k}^{20}$ menemukan indeks sTfR-F berkorelasi dengan saturasi transferin dan indeks eritrosit; sedangkan kadar feritin dan sTfR berkorelasi secara bermakna dengan saturasi transferin.

Pemeriksaan saturasi transferin dilakukan pada 125 bayi yang tidak menderita ADB, yang berusia 0-6 bulan. Insidens deplesi besi pada bayi dari ibu dengan anemia dan ibu tanpa anemia berturut-turut 32,4\% dan 25,9\%. Secara keseluruhan dari 211 bayi, insidens deplesi besi $28,0 \%$ dan insidens paling tinggi terjadi 
pada bayi berusia 0 bulan $9,5 \%$. Insidens defisiensi besi pada bayi dari ibu anemia dan ibu tanpa anemia berturut-turut $16,2 \%$ dan 32,2\%. Secara keseluruhan insidens defisiensi besi 27,0\%, dan paling tinggi terdapat pada bayi berusia 0 bulan $14,2 \%$. Ervasti $\mathrm{dkk}^{20}$ melaporkan 9 bayi $(4,5 \%)$ dari 199 bayi baru lahir menderita defisiensi besi (batasan defisiensi besi adalah bila saturasi transferin $<30 \%$ ).

Pada pengamatan saat usia bayi 6-12 bulan, dari 59 bayi yang menderita deplesi besi ditemukan 12 bayi tetap deplesi besi, 4 bayi menjadi defisiensi besi, 5 bayi menjadi ADB. Dari 57 bayi yang menderita defisiensi besi, 11 tetap defisiensi besi, 11 menjadi deplesi besi, dan 9 menjadi ADB. Dari 9 bayi yang mempunyai status besi sebelumnya normal, 1 menjadi deplesi besi, dan 1 menjadi defisiensi besi. Jadi secara keseluruhan dalam rentang 12 bulan, $24(11,4 \%)$ menderita deplesi besi, $16(7,6 \%)$ menderita defisiensi besi, dan 100 bayi (47,4\%) menderita ADB (Tabel 2 dan Tabel 3). Insidens $\mathrm{ADB}$ cenderung lebih sering terjadi pada bayi berusia 0-2 bulan dan 12 bulan [72 (72\%) dari 100 bayi ADB), dan 12 bulan, baik pada bayi yang lahir dari ibu anemia maupun tanpa anemia.

Sudah banyak penelitian yang mengungkapkan fakta bahwa ADB sudah terjadi dalam rentang usia bayi 0-6 bulan, apalagi pada usia 6-12 bulan. Beberapa penelitian menunjukkan bahwa bayi baru lahir aterm dari ibu anemia mempunyai kadar feritin dan saturasi transferin yang lebih rendah dibandingkan bayi baru lahir aterm dari ibu tanpa anemia. ${ }^{12,25,26}$ Demikian juga Kelly dkk ${ }^{27}$ dan Fenton $\mathrm{dkk}^{28}$ melaporkan bayi baru lahir aterm dari ibu dengan defisiensi besi tanpa anemia mempunyai kadar feritin yang lebih rendah dibandingkan bayi baru lahir aterm dari ibu dengan status besi yang normal. Siegel $\mathrm{dkk}^{21}$ dalam penelitiannya menyimpulkan bahwa faktor risiko usia bayi adalah faktor risiko utama yang dapat menyebabkan kecenderungan seorang bayi akan menderita ADB atau defisensi besi. Semakin bertambah usia bayi semakin besar risikonya menderita defisiensi besi atau ADB.

Respons kenaikan nilai hemoglobin setelah pemberian zat besi pada bayi yang ADB merupakan bukti paling kuat bahwa bayi benar-benar menderita ADB. Pada penelitian kami pemberian zat besi elemental $4-5 \mathrm{mg} / \mathrm{kgBB} /$ hari selama $2-3$ bulan yang dimulai pada saat terjadi ADB dapat memulihkan kadar hemoglobin bayi menjadi normal. Kemudian pada semua bayi yang mempunyai hemoglobin telah normal, terapi zat besi dilanjutkan selama dua bulan untuk mengisi cadangan zat besi di dalam tubuh.

Dari hasil penelitian kami disimpulkan deplesi besi, defisiensi besi, dan ADB sudah ada sejak bayi lahir maka perlu segera dilakukan tindakan pencegahan agar tumbuh kembang bayi dapat berlangsung optimal. Insidens deplesi besi, defisiensi besi, ADB pada bayi 0-12 bulan berturut-turut $11,4 \%, 7,6 \%$, dan $47,4 \%$, tertinggi pada bayi berusia 0 bulan, berturut-turut $9,5 \%, 14,2 \%$, dan $11,8 \%$. Insidens $\mathrm{ADB}$ cenderung lebih tinggi pada bayi yang lahir dari ibu dengan anemia daripada bayi yang lahir dari ibu tanpa anemia.

\section{Daftar pustaka}

1. Schneider JM, Fujii ML, Lamp CL, Lonnerdal B, Dewey KG, Zidenberg-Cherr S. Anemia, iron deficiency, and iron deficiency anemia in 12-36-mo-old children from low-income families. Am J Clin Nutr 2005;82:126975.

2. Helen Keller International (Indonesia). Iron deficiency anemia in Indonesia. Report of the policy workshop on iron deficiency anemia in Indonesia. Jakarta: 1997.h.116.

3. Lozoff B. Iron deficiency in infancy: applying a physiologic framework for prediction. Am J Clin Nutr 2006;84:141221.

4. Untoro R, Falah TS, Atmarita, Sukarno R, Kemalawati R, Siswono. Anemia gizi besi. Dalam: Untoro R, Falah TS, Atmarita, Sukarno R, Kemalawati R, Siswono, penyusun. Gizi dalam angka sampai dengan tahun 2003. Jakarta: DEPKES; 2005.h.41-4.

5. Pee S, Bloem MW, Sari M, Kiess L, Yip R, Kosen S. The high prevalence of low hemoglobin concentration among Indonesian infants aged 3-5 months is related to maternal anemia. J Nutr 2002;132:2215-21.

6. Lozoff B, Andraca I, Castilo M, Smith BS, Walter T, Pino P. Behavioral and development effects of preventing irondeficiency anemia in healthy full-term infants. Pediatrics 2003;112:846-54.

7. Halterman JS, Kaczorowski JM, Aligne A, Auinger P, Szilagyi PG. Iron deficiency and cognitive achievement among school-aged children and adolescents in the United states. Pediatrics 2001;107:1381-6.

8. Algarin C, Peirano P, Garrido M, Pizarro F, Lozoff B. Iron deficiency anemia in infancy: long-lasting effects on auditory and visual system functioning. Pediatr Res 2003;53:217-23. 
9. Lundstorm UL, Siimes MA, Dallman PR. At what age does iron supplementation become necessary in lowbirth-weight infants? J Pediatr 1977;91:878-83.

10. Rios E, Lipschitz DA, Cook JD, Smith NJ. Relationship of maternal and infant iron stores as assessed by determination of plasma feritin. Pediatrics 1975;55: 694-9.

11. Saarinen UM, Siimes MA. Developmental changes in serum iron, total iron-binding capacity, and transfering saturation in infancy. J Pediatr 1977;91:875-7.

12. Ziaei S, Hatefnia E, Togeh Gh. Iron status in newborns born to iron-deficient mothers. Iran J Med Sci 2002; 28:62-4.

13. Kilbride J, Baker TG, Parapia LA, Khoury SA, Shuqaidef, Jerwood D. Anaemia during pregnancy as a risk factor for iron-deficiency anaemia in infancy: a case-control study in Jordan. Int J Epid 1999;28:461-8.

14. Erhardt JG, Estes JE, Pfeiffer CM, Biesalski HK, Craft NE. Combined measurement of ferritin, soluble transferrin receptor, retinol binding protein, and C-reactive protein by an inexpensive, sensitive, and simple sandwich enzyme-linked immunosorbent assay technique. J Nutr 2004;134:3127-32.

15. Dallman PR. Iron deficiency anemia: a synthesis of current scientific knowledge and U.S. recommendations for prevention and treatment. Dalam: Earl R, Woteki $\mathrm{CE}$, penyunting. Iron deficiency anemia: recommended guidelines for prevention, detection, and management among U.S children and women of childbearing age. Didapat dari: http://www.nap.edu/catalog/2251.html.

16. Andrews NC. Iron deficiency and related disorders. Dalam: Greer JP, Foerster J, Lukens JN, Rodgers GM, Paraskevas F, Glader B, penyunting. Wintrobe's Clinical Hematology. Edisi kesebelas, vol 1. Philadelphia: Lippincott William \& Wilkins; 2004.h.979-1009.

17. Glader B. Anemia: general considerations. Dalam: Greer JP, Foerster J, Lukens JN, Rodgers GM, Paraskevas F, Glader B, penyunting. Wintrobe's clinical hematology. Edisi kesebelas, vol 1. Philadelphia:Lippincott William \& Wilkins; 2004.h.947-78.

18. Smith H. Normal values and appearance. Dalam: Smith $\mathrm{H}$, penyunting. Diagnosis in paediatric haematology.
New York:Churchill Livingstone; 1996.h.1-33.

19. Yip R, Walsh KM, Goldfarb MG, Binkin MJ. Declining prevalence of anaemia in childhood in a middleclass setting: a paediatric success story? Pediatrics 1987;80:330-4.

20. Ervasti M, Kotisaari S, Senkilampi U, Heinonen S, Punnonen K. The relationship between red blood cell and reticulocyte indices and serum markers of iron status in the cord blood of newborns. Clin Chem Lab Med 2007;45:1000-3.

21. Siegel EH, Stoltzfus RJ, Khatry SK, LeClerq S, Katz J, Tielsch JM. Epidemiology of anemia among 4-to 17month children living in South Central Nepal. Eur J Clin Nutr 2006;60:228-35.

22. Sekartini R, Soedjatmiko, Wawolumaya C, Yuniar I, Dewi R, Nycane. Prevalensi anemia defisiensi besi pada bayi usia 4-12 bulan di Kecamatan Matraman dan sekitarnya, Jakarta Timur. Sari Pediatri 2005;7:2-8.

23. Ringoringo HP, Windiastuti E. Profil parameter hematologik dan anemia defisiensi zat besi bayi berumur 0-6 bulan di RSUD Banjarbaru. Sari Pediatri 2006;7:214-8.

24. Meinzen-Derr JK, Guerrero ML, Altaye M, OrtegaGallegos H, Ruiz-Palacios GM, Morrow AL. Risk of Infant Anemia Is Associated with exclusive breast-feeding and maternal anemia in a Mexican Cohort. J. Nutr 2006;136:452-8.

25. Agarwal RMD, Tripathi AM, Agarwal KN: Cord blood hemoglobin, iron and ferritin status in maternal anemia. Acta Paediatr Scand 1983;72:545-8.

26. Erdem A, Erdem M, Arslan M, Yazici G, Eskandari R, Himmetoglu O: The effect of maternal anemia and iron deficiency on fetal erythropoiesis: comparison between serum erythropoietin, hemoglobin and ferritin levels in mothers and newborns. J Matern Fetal Neonatal Med 2002;11:329-32.

27. Kelly AM, MacDonald DJ, Mc Dougall AN: Observations on maternal and fetal ferritin concentrations at term. Br J Obstet Gynaecol 1978;85:338-43.

28. Fenton V, Cavill I, Fisher J: Iron stores in pregnancy. Br J Haematol 1977;37:145-9. 